\title{
Енисейские рунические надписи Яр-хото (Из находок первой археологической экспедиции Академии наук в Восточный Туркестан)
}

Кызласов Игорь Леонидович, Институт археологии РАН (Москва); kyzlasovil@mail.ru

В 1898 г. Д. А. Клеменцем в Турфанском оазисе был обследован небольшой пещерный монастырь близ древнего города Яр-хото. На стенах двух жилых пещер (номер 3 и 6) были обнаружены и скопированы 13 граффити, выполненных так называемым енисейским руническим письмом. По возвращению в Санкт-Петербург надписи были сразу же изучены и определены В. В. Радловым, издавшим четыре эстампажа надписей, их прочтение и перевод. В дальнейшем по архивным копиям все граффити были исследованы и прочитаны М. Эрдалом. Тюркологи, включая С. Г. Кляшторного, считали их отметками проезжих путешественников. Новые исследования и прочтения, предлагаемые в данной статье, связывают эти надписи с известными на Саяно-Алтайском нагорье многочисленными манихейскими молитвенными начертаниями, выполненными енисейскими рунами. По скоплению таких надписей в Южной Сибири выделены места, где в раннем средневековье существовали манихейские монастыри. Следовательно, и близ Яр-хото граффити были оставлены монахами - выходцами из Древнехакасского государства. И сделано это было в IX-X вв. Обследованный в 1898 г. пещерный монастырь был манихейским, на что указывает описанная в письменных источниках форма его центрального храма (пещера 4), имевшего пять сакральных камер, обязательных для таких богослужебных помещений. Дальнейшее изучение надписей должно исходить из их религиозного назначения и принадлежности к северному, сибирско-тюркскому варианту манихейства.

Ключевые слова: Восточный Туркестан, Турфанский оазис, Яр-хото, пещерный монастырь, енисейское руническое письмо, северное манихейство

\section{YENISEI RUNIC INSCRIPTIONS OF YAR-KHOTO (FROM THE FINDS OF THE FIRST ARCHAEOLOGICAL EXPEDITION OF THE ACADEMY OF SCIENCES TO EAST TURKESTAN)}

Igor L. Kyzlasov, Institute of Archaeology RAS; kyzlasovil@mail.ru

In 1898, Dmitry A. Klements examined a small cave monastery in the Turfan oasis near the ancient city of Yar-Khoto. On the walls of two residential caves (nos. 3 and 6), 13 graffiti in the so-called Yenisei runic script were discovered and copied. Upon Klements' returning to St. Petersburg, the inscriptions were immediately studied and identified by Academician Wilhelm Radloff (in Russian Vasily V. Radlov), who published four prints of the inscriptions, their reading and translation. Later, using archival copies, all graffiti were examined and read by Marcel Erdal. Turkologists, including Sergei G. Klyashtornyi, considered them to be marks of passing travelers. New insights and readings offered in this article link these inscriptions with the numerous Manichean prayer inscriptions made in the Yenisei runes known in the Sayan-Altai highlands. Based on the accumulation of such inscriptions in Southern Siberia, the places where Manichean monasteries existed in the early Middle Ages have been identified. Therefore, graffiti near Yar-Khoto were also left by monks who came from the Ancient Khakass state, and this was done in the 9th-10th centuries. The cave monastery surveyed in 1898 was Manichean, as indicated by the form of its central temple (cave 4) described in written sources, which had five sacred chambers, mandatory for such places of worship. Further study of the inscriptions should proceed from their religious purpose and their belonging to the northern, Siberian-Turkic version of Manicheism.

Keywords: East Turkestan, Turfan oasis, Yar-khoto, cave monastery, Yenisei runic writing, northern Manichaeism

Работа выполнена в рамках государственного задания АААА-А18-118011790092-5 «Археологические и антропологические источники и верификация гипотез: методические аспекты фундаментального знания и полевых исследований» 
В XIX в. для европейских и российских путешественников, преследовавших разные цели, археологические памятники Восточного Туркестана оставались лишь любопытными попутными объектами, иногда заслуживавшими упоминания и описания (историю изучения см. [Литвинский, Терентьев-Катанский 1988]). Иной взгляд на древности региона, в начале ХХ в. проявившийся в их длительном и целенаправленном изучении учеными Пруссии, Британии, Франции и Японии, был вызван ошеломляющим успехом первой специальной археологической экспедиции Российской академии наук 1898 года.

Она носила разведочный характер, состояла всего из трех сотрудников, обладала скромными средствами, продолжалась лишь четыре месяца, из которых в самом Восточном Туркестане проработала только два. Но именно она впервые показала наполненность района исключительно ценными объектами средневековой культуры: руинами городов, наземных и пещерных монастырей и храмов, сохранивших великое множество культовых скульптур и многоцветных настенных росписей, а также, благодаря климату, бумажных документов, покрытых разными письменами на уйгурском, китайском, санскрите и иных языках. Полевые описания Турфанской экспедиции, планы, рисунки, фотоснимки, эстампажи дополнялись небольшим числом купленных рукописей, собранных предметов, образцами оригинальных настенных росписей, отражавших разные художественные стилистические манеры [Ольденбург 1917: 7-11].

Руководивший той экспедицией Дмитрий Александрович Клеменц - видный революционернародоволец, отбывший более двух с половиной лет в бастионе Петропавловской крепости, - был в 1881 г. сослан на Енисей в Минусинск, где пробыл почти 15 лет, стал деятельным сотрудником Минусинского музея и немало способствовал его известности в научном мире. К 1898 г. он уже был опытным путешественником, большим знатоком южносибирских и монгольских древностей, включая памятники рунической эпиграфики и историю их изучения [Попов 1925: 43-58]. В Турфанской экспедиции его, как и во всех предшествующих, сопровождала жена Елизавета Николаевна, а также переводчиквостоковед Михаил Степанович Андреев (см. о нем [Акрамова, Акрамов 1973], о работе в экспедиции с. $40,41,51)$.

Сама же «экспедиция была снабжена фотографическим аппаратом, инструментами для съемки и для эстампирования надписей» [Ольденбург 1917: 1-2], т. е. отдельной задачей имела поиски письменных памятников, включая эпиграфические.

Текст до сих пор не изданного отчета экспедиции, поступивший в Азиатский музей Академии наук и ныне хранящийся в архиве Института восточных рукописей РАН (СПб), послужил основой для опубликованной исследователем статьи на немецком [Klements 1899].

«В местности Яргул, что служит западными воротами Турфанского оазиса» [Туманова 1989: 15], в окрестностях средневекового городища экспедицией было сделано исключительно важное для истории культуры открытие, все еще недостаточно оцененное в науке.

Согласно С. Ф. Ольденбургу [Ольденбург 1917: 5, 8], в дневниках Д. А. Клеменц пишет о речке Яр, «старом городе на Яре» или «древнем городе на Яре», называет городище тем же именем, что и реку: «развалины древнего города - Яр». В отдельном примечании сам побывавший в Турфане Сергей Федорович оговаривает [там же: 8]: «В дневниках Д. А. всюду правильное название Яр; в книге ([Klements 1899]. - И. К.) почему-то взято совершенно неизвестное и неупотребительное Яр-хото. Русский аксакал в Турфане $\langle\ldots\rangle$ Ахрор-хан Тюря говорил нам в 1909 году, что Д. А. почему-то называл город Яр-хото, и что после него некоторые тоже стали употреблять неизвестное до того и неправильное "Яр-хото"». Сам С. Ф. Ольденбург продолжал именовать памятник городом на Яре [Туманова 1989: 17], так же именует тамошние объекты в своей статье 1916 г. изучавший их С. М. Дудин [Дудин 1916а: 217-220, 241, 242; 1916б: 45-50, 53-57, 60, 63, 64, 73 $]^{1}$. Следуя документам экспедиции 1909-1910 гг., О. А. Туманова всюду пишет о древнем городище «остров Яр».

Однако наименование Яр-хото, искусственное в отношении местного уйгурского (хото - монгольское слово «город», современная его форма - xоm [MРС 1957: 543]), вероятно, имело некоторые основания, поскольку Н. Я. Бичурин указывает для этих руин позднее монгольское «Чжоха-хота». Так или иначе, но благодаря публикации Д. А. Клеменца 1899 г. именно название Яр-хото стало общепринятым в русской и европейской литературе. Оно используется даже отечественными синологами при переводе раннесредневековых китайских источников (см., например, [Малявкин 1974: 90]). Китайское же наименование древнего города, известного со 108 г. до н. э., а затем и его городища - Цзяохэчэн (Јiaohe cheng, «Город в сплетении рек, Город в междуречье») [Бичурин 1950: 206, 207, прим. 1; Крюков 1988: 291].

Город занимал длинный останец высотой 30 м и площадью 1700 м х 300 м, охваченный двумя протоками р. Яр (местное имя долины - Yarnaiz [Jiaohe 2001: 3, 27]). По обоим обрывистым берегам близ

${ }^{1}$ Статья С. М. Дудина, печатавшаяся с продолжением в нескольких номерах журнала [Дудин 1916а], тогда же была издана отдельной книгой [Дудин 1916б]. Нумерация страниц в двух публикациях, разумеется, не совпадает. 
него гнездились пещерные объекты и монастыри. В одном из них и были обнаружены Д. А. Клеменцем интересующие нас надписи. По описаниям, наброскам чертежей и фотоснимкам 1909 г., сделанным участниками Первой Русской Туркестанской экспедиции Самуилом Мартыновичем Дудиным и Дмитрием Арсеньевичем Смирновым, монастырь был отождествлен с Объектом VII (рис. 1). В журнальной публикации 1916 года был издан фотоснимок фасада хорошо сохранившегося верхнего яруса этого пещерного комплекса [Дудин 1916а: 243; 1916б: 60] (рис. 2), судя по изданному там же плану, сделанный с северозапада. Сопровождающий эти материалы текст краток: «Из пещерных сооружений наибольший интерес представляет комплекс 8 пещер, образовавший, по-видимому, маленький монастырек. Пещеры его расположены в два яруса и представляют одно архитектурное целое. Нижний ярус разрушен. В пещерах верхнего яруса сохранилась местами роспись» [Дудин 1916: 242; 1916б: 57, 58].

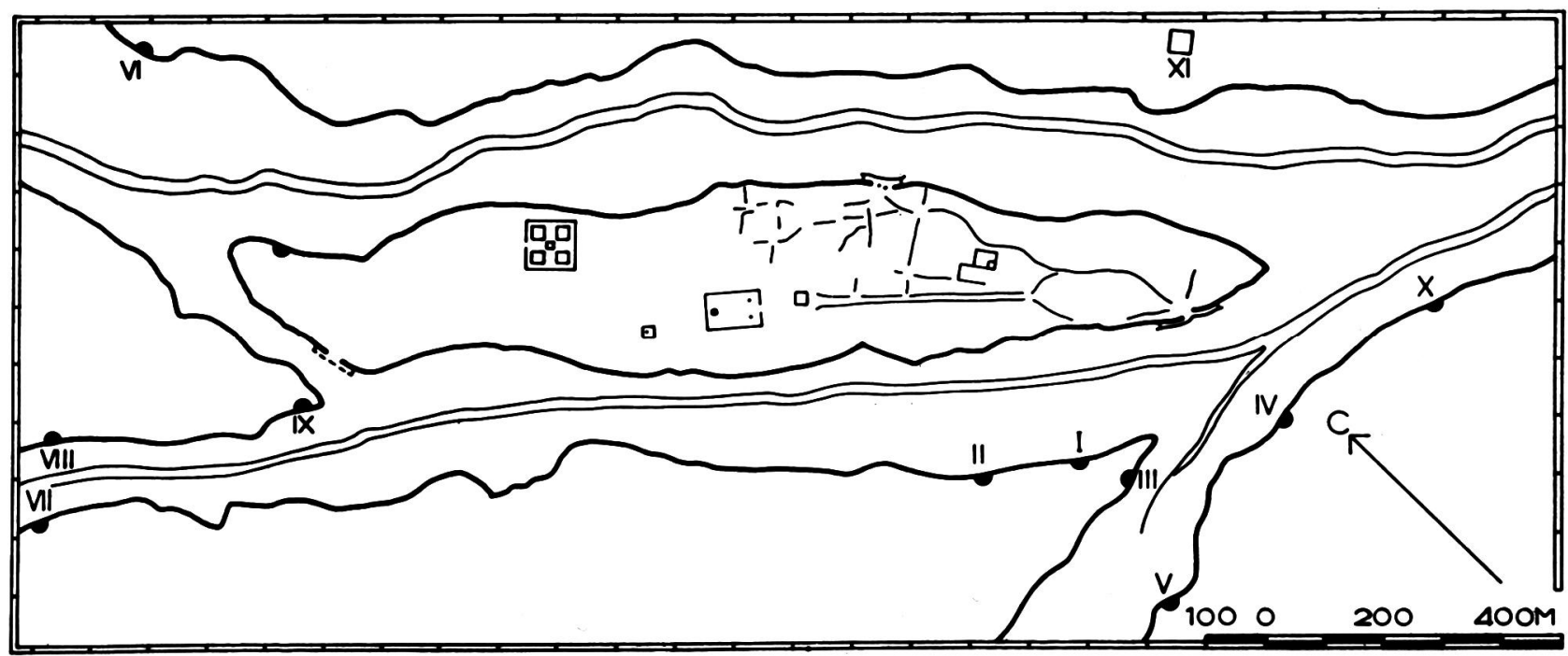

Puc. 1. Турфанский оазис. Схема окрестностей острова с городищем Яр-хото:

объекты I, IV, VI, VIII-X — комплексы пещер; II, III — погребальные ниши; VII, XI — пещерные монастыри.

Современная сводка планов А. Стейна и Гуань Миня [Туманова 1989: рис. 2]

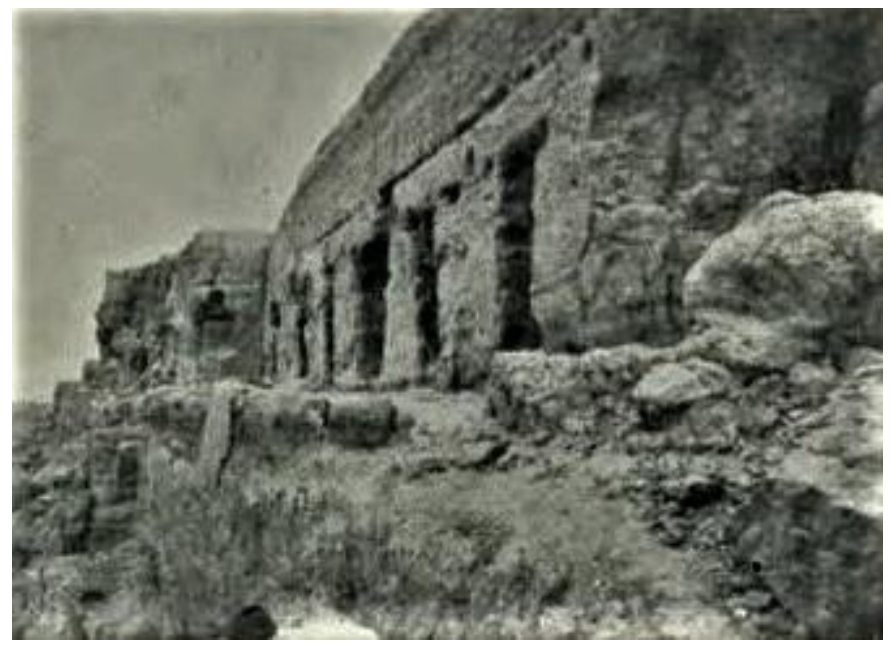

Рис. 2. Яр-хото. Объект VII. Пещеры верхней площадки. Фото 1909 г. [Дудин 1916а: 243; 1916б: 60]

Согласно имеющимся в литературе кратким выпискам, об условиях эпиграфических находок в рукописном отчете Д. А. Клеменца сказано: «В Яр-хото, в пещерах без живописи, служивших жилыми помещениями, мы нашли ряды нацарапанных на штукатурке рунообразных надписей. Надписи эти были репродуцированы нами посредством эстампажа» ([Клеменц. Краткий перечень. Л. 52]; цит. по [Кляшторный 1992: 336, 337; 2003: 373], cp. [Klementz 1899: 47]). 
В другом отчете, также оставшемся неизданным, данные конкретнее и могут быть привязаны к определенным объектам: «В шестой и третьей пещерах стены покрыты глиной, и на них среди разной мазни, нашли мы рунические надписи. Они сняты (сделаны эстампажи. - И. К.), одна из них скопирована от руки» ([Клеменц. Описание. Л. 5, рисунок надписи от руки карандашом - Л. 3]; цит. по: [Кляшторный 1992: 337; 2003: 374]). Первоначально таких надписей было больше: пересказывая текст Д. А. Клеменца, С. Г. Кляшторный [Кляшторный 2003: 374] пишет, что, кроме того, и «в пещерах, разрушенных обвалами (вероятно, речь о пещерах нижнего яруса Объекта VII. - И. К.), были обнаружены обрывки “полностью испорченных рунических надписей”». Поскольку речь идет о надписях, а не о рукописях, можно думать, что слово «обрывки» обозначало здесь части граффити на стенной штукатурке.

«Несмотря на непонятное отсутствие указаний в дневнике, несомненно, что именно ко времени между 9 сентября и 14 относится» обнаружение рунических надписей на стенах монастырских жилищ [Ольденбург 1917: 5] $]^{2}$. Всего Д. А. Клеменцем были документально зафиксированы 13 рунических граффити - сделаны 12 эстампажей на ткани и один рисунок карандашом.

Среди опубликованных фотоснимков Д. А. Клеменца есть виды камер двух храмовых пещер с росписями, входящих в этот монастырь: одна из них - пещера 1 [Туманова 1989: рис. 40], другая не опознана издателями [Бухарин, Шевельчинская 2018: 281, 282, № 4, 5], но по чертежам и описаниям Д. А. Смирнова и С. М. Дудина ясно, что это пещера 4. У Д. А. Клеменца были особые причины печатать именно ее снимок [Klementz 1899: P1. 3], но об этом ниже.

По архивным материалам Первой Русской Туркестанской экспедиции 1909 г. 80 лет спустя был не только составлен и издан подробный чертеж - план, фасад и разрезы - этого наиболее значительного пещерного монастыря на Яре (рис. 3), но и издано описание его пещер, имеющееся в рукописной работе С.М. Дудина «Развалины Яр-хото» и полевой тетради Д. А. Смирнова [Туманова 1989: 49-51, рис. 39]. Это «продолговатые сводчатые помещения с высокими арочными входами. Входы в пещерах 1, 4 и 7 широкие, в остальных узкие, вход в пещеру 8 разрушен $\langle\ldots\rangle$ (счет идет снизу с юго-вост.) (Как видим, экспедиция 1909 г. сохранила нумерацию пещер, данную Д. А. Клеменцем. - И. К.) 〈...〉 В пещерах 3, 5, 6 в стенах имеются глубокие ниши (см. план) арочных очертаний также (как камеры пещеры 4. - И. К.) без следов обмазки. 〈...〉 Пещеры 1 и 4 сохранили роспись стен и потолка» [Туманова 1989: 50].

Поскольку пещеры этого монастыря делятся на храмовые и жилые, широкие входы отличают первую, культовую группу (в чем убеждает указание на росписи и упомянутые выше опубликованные фотоснимки пещер 1 и 4), а узкие, некогда для тепла закрывавшиеся дверями, - вторую, жилую. Ниши в стенах, служившие полками, также подтверждают бытовое назначение пещер 3, 5 и 6. Составленные и изданные чертежи позволяют с определенной точностью измерить не оговоренные в изданной части рукописи размеры культовых и жилых пещер. Храмовая пещера 1 без вестибюля имеет ширину 3 м и длину более 5 м, жилые камеры близки по площади: наименьшая, под номером 2, по ширине несколько более 2,5 м и 5 м в длину, 3-я - 3 м на почти 6 м, 5-я - 3 м на несколько более 5 м, 6-я - 3,5 х 5,6 м. Площади их составляют около 12,5, 15, 18 и 19,6 кв. м соответственно.

Ориентируясь на третью и шестую жилые пещеры, в рукописи названные самим Дмитрием Александровичем, находим прямое указание С. М. Дудина: «В пещере 3 на стенах много нацарапанных тюркских надписей» [Туманова 1989: 50]. Так благодаря документации Самуила Марковича удается точно связать полученные Д. А. Клеменцем эпиграфические материалы с конкретным монастырем, его планом и пещерными объектами. Видимо, большинство эстампированных в 1898 г. рунических граффити находилось в пещере 3 , а в пещере 6 их было встречено меньше.

Остается отметить, что, согласно данным петербургского тюрколога Дмитрия Владимировича Рухлядева, еще в 2010 г. в пещерах Объекта VII (по С. М. Дудину, «монастырька») на р. Яр сохранялись оригиналы этих настенных граффити. В популярных изданиях о древностях, осуществленных в Китае, находим современный фотоснимок хорошо сохранившегося фасада этого монастыря (рис. 4), рядом с которым издан и его общий план, снятый русской экспедицией (но нумерация пещер дана обратная от северо-запада к юго-востоку; как видим по фото С. М. Дудина (рис. 2) - со стороны подъема на верхнюю площадку) [Jiaohe 2001: 27].

Доставленные в Петербург копии рунических надписей были сразу же изучены В. В. Радловым, равно как и все иные письменные памятники, открытые экспедицией 1898 г. Сопровождая обзорную статью Д. А. Клеменца тюркологической публикацией, маститый лингвист издал фотоснимки четырех его эс-

\footnotetext{
${ }^{2}$ Ныне этот дневник издан [Бухарин, Инкина 2018], так же как и фотоархив экспедиции [Бухарин, Шевельчинская 2018] (см. также [Туманова 1989: 13, прим., рис. 36, 37]). Записи не связаны с археологией, в них ничего нет о пещерном монастыре и лишь упомянуты виденные 9 сентября «на противоположной стороне развалины древнего города Яр» [там же: 251, л. 84].
} 


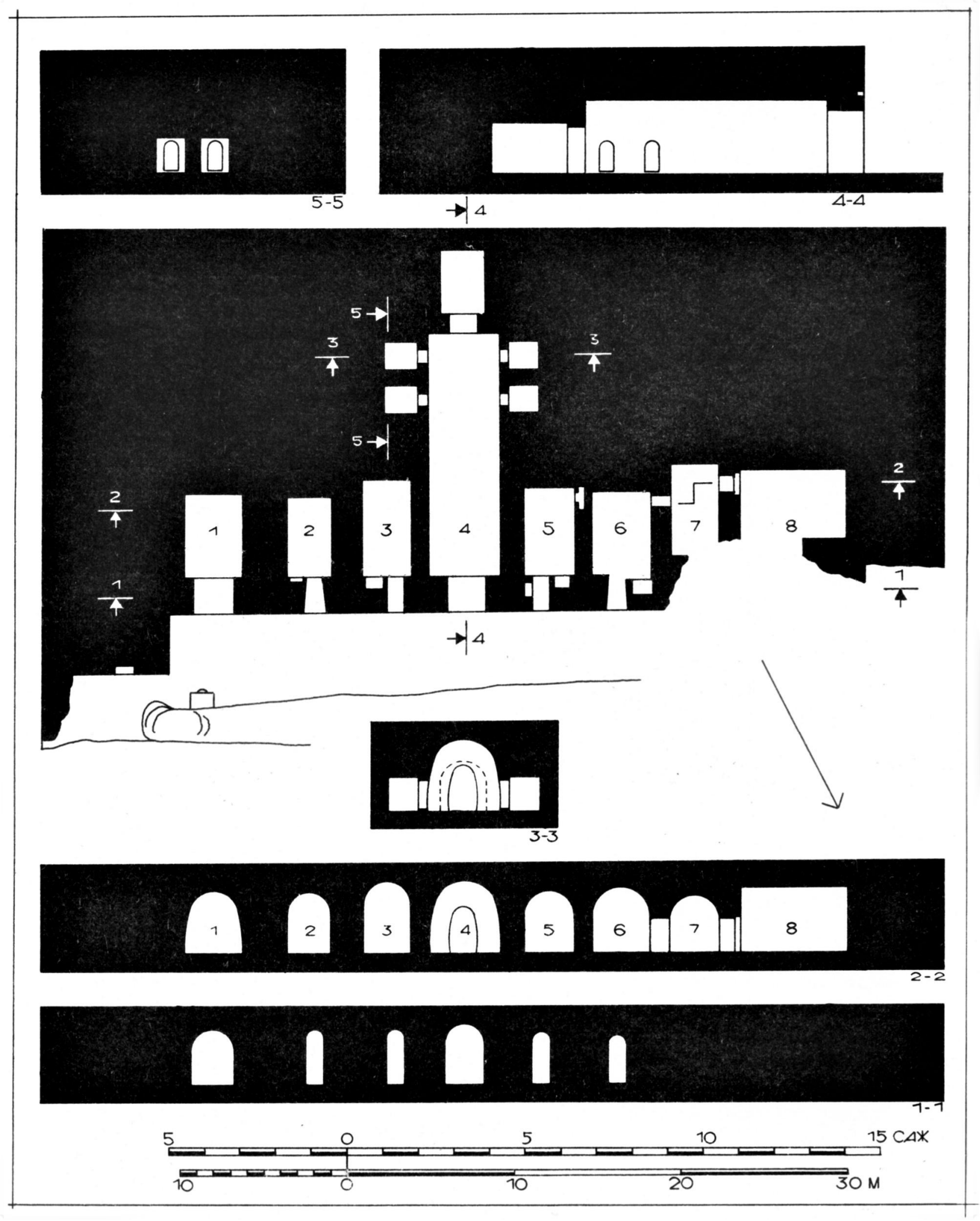

Puc. 3. Яр-хото. Объект VII. Пещерный монастырь. План, фасад и разрезы.

Составлен по материалам Первой Русской Туркестанской экспедиции 1909 г. [Туманова 1989: рис. 39] 


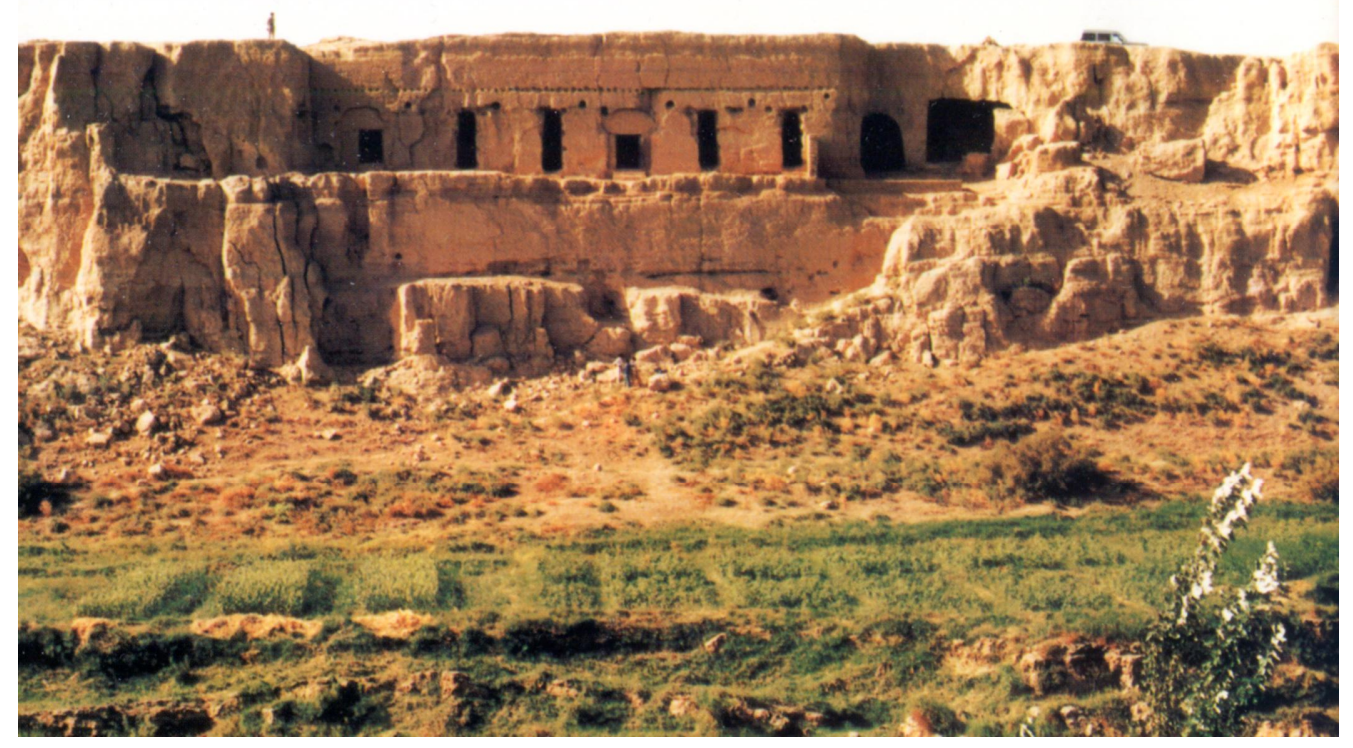

Puc. 4. Яр-хото. Объект VII. Вид пещерного монастыря к началу 2000-х гг. [Jiaohe 2001: 27]

тампажей, лучше прочих воспроизводивших резные строки. Хотя эти надписи «очень короткие, и их расшифровка представляет большие трудности, поскольку стены (на которых их вырезали. - И. К.) были в последующем исписаны много раз», ученый предложил их транскрипцию и перевод на немецкий. Особую значимость избранных им репродукций В. В. Радлов видел в их палеографической, а следовательно, и историко-культурной характеристике: они «ясно доказывают, что эти надписи написаны древнетюркским алфавитом, а именно таким, форма букв которого почти идентична надписям с Верхнего Енисея» [Radloff 1899: 57, 80-82].

В последующее 27 лет, как и по сей день (историю изучения см. [Erdal 1993: 87-88]), тюркологи довольствовались изданием Радлова. Лишь в 1926 г. присланный великим дешифровщиком рун Вильгельмом Томсеном его ученик Курт Вульф привез своему мэтру из Азиатского музея копии всех 13 граффити Яр-хото. В Копенгагене датский тюрколог работал тогда над полным сводом известных памятников азиатского рунического письма. Но в 1927 г. работа прекратилась - помешала смерть В. Томсена.

Через 45 лет, в 1970-х гг., с коллекцией работал лингвист из Иерусалима М. Эрдал. Еще через 20 лет, после посещения Копенгагена, он издал статью, посвященную пещерным надписям, открытым Д. А. Клеменцем за сотню лет до этого [Erdal 1993]. На 12 эстампажах оказалось 11 надписей (два оттиска сошлись в одну строку), для каждой из которых исследователь предложил транслитерацию, транскрипцию и английский перевод. Однако статья современного тюрколога в источниковедческом смысле неполна. То ли по условиям публикации, то ли из-за примата лингвистического интереса в ней нет воспроизведения самих надписей. Тем самым, нет возможности проверить предложенные прочтения и судить о палеографии, оговоренной автором для 7 настенных граффити. Отыскивая аналогии в сводных трудах Д. Д. Васильева [Васильев 1983а, б], М. Эрдал выделил в этих строках 6-7 форм знаков, отличающих енисейские памятники от орхонских. Помимо этого, исследователь указал на надписи, выполненные одной рукою, и на несколько граффити, составлявших единые строки [Erdal 1993: 90—92, 95, 98] ${ }^{3}$.

В начале XXI в. работа по описанию Фонда Центральной Азии и Сибири в архиве ИВР РАН охватила и «Коллекцию Клеменца (Турфан)». Согласно сведениям, доброжелательно сообщенным мне занимавшимся этой работой к. и. н. Д. В. Рухлядевым (письма от 27.12.17 г. и 8.11.20 г.), в ней сохранились все рунологические материалы из Яр-хото: 12 эстампажей и 1 рисунок. Долго остававшиеся недоступными для исследователей, они в 2003 г. были осмотрены С. Г. Кляшторным (1928-2014), который собирался заняться ими. Ранее ученый писал лишь о четырех настенных надписях [Кляшторный 1964: 52, 53; 2003 : 43, 44, 365, но: 366; Кляшторный, Лубо-Лесниченко 1974: 47]; по крайней мере с 1992 г. в его публикации вошли сведения из архивных рукописей Д. А. Клеменца.

Предстоит изучение и полноценное издание этих редкостных архивных источников. Необходимо и новое исследование самих настенных рунических надписей на р. Яр.

${ }^{3}$ Благодарю проф. М. Эрдала, специально приславшего для меня через редколлегию журнала с. 102, отсутствовавшую в доступных версиях его статьи [Erdal 1993]. 
Вывод В. В. Радлова о енисейской алфавитной принадлежности надписей Яр-хото не раз подтверждался отечественными эпиграфистами. С. Г. Кляшторный, дополняя местную серию находками последующих лет, относил к енисейским письменам все резные надписи, известные в Восточном Туркестане [Кляшторный 1992: 338; 2003: 375; 2010: 278]. Ныне к граффити на стенах жилых и храмовых пещер, а также на бронзовом зеркале следует добавить енисейскую эпитафию, найденную близ древнего Бешбалыка [Кызласов 2016].

Четыре эстампажа, избранных для публикации В. В. Радловым (рис. 5-8; номера его иллюстраций 26-29 далее обозначают надписи), позволяют видеть употребление характерных енисейских рунических

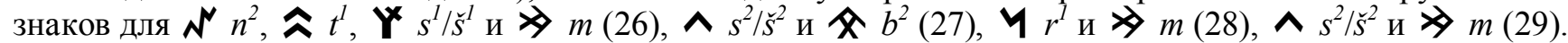
Однако $\boldsymbol{N}^{\mathbf{N}} n^{2}$, $b^{2}$ или $\mathbf{Y} s^{1} / s^{1}$ такого облика порознь встречаются и в младшем орхонском письме как на стелах Уйгурского каганата (Моюн-чора, Тэсинской, Терхинской, Карабалгасунской), так и в рукописях Восточного Туркестана. Обычны для них и формы рун $\mathbf{Y} r^{l}$ и $\gg \boldsymbol{m}$, встреченные в Яр-хото. Хотя во всем этом следует видеть отмеченное по иным материалам возрастающее влияние енисейского письма на позднеорхонское, строго говоря, сугубо показательными здесь являются лишь енисейские руны $\boldsymbol{\wedge} t^{1}$ и $\widehat{\wedge} s^{2} / \breve{s}^{2}$ [Кызласов 1994: 81-83, 92, табл. XXV]. В нашем случае особенно много значит использование всех названных разновидностей букв в сочетании друг с другом. Несмотря на существование енисейского курсивного письма, известного и в камнеписной практике [Кызласов 1994: 147, 156, 157, рис. 12], настенные монастырские граффити, судя по изданным образцам, выполнены наиболее распространенными прямолинейными лапидарными начертаниями.

Рунические письменности - как енисейская, так и орхонская - имели официальный статус в конкретных раннесредневековых государствах Центральной Азии и Южной Сибири [Кызласов 1994: 210232]. Поэтому в данном случае алфавитная принадлежность монастырских граффити, несомненно, указывает на выходцев из Древнехакасского государства, для периода VIII-XI вв., согласно политическому определению, использовавшемуся за рубежами страны, называемого также Кыргызским каганатом.

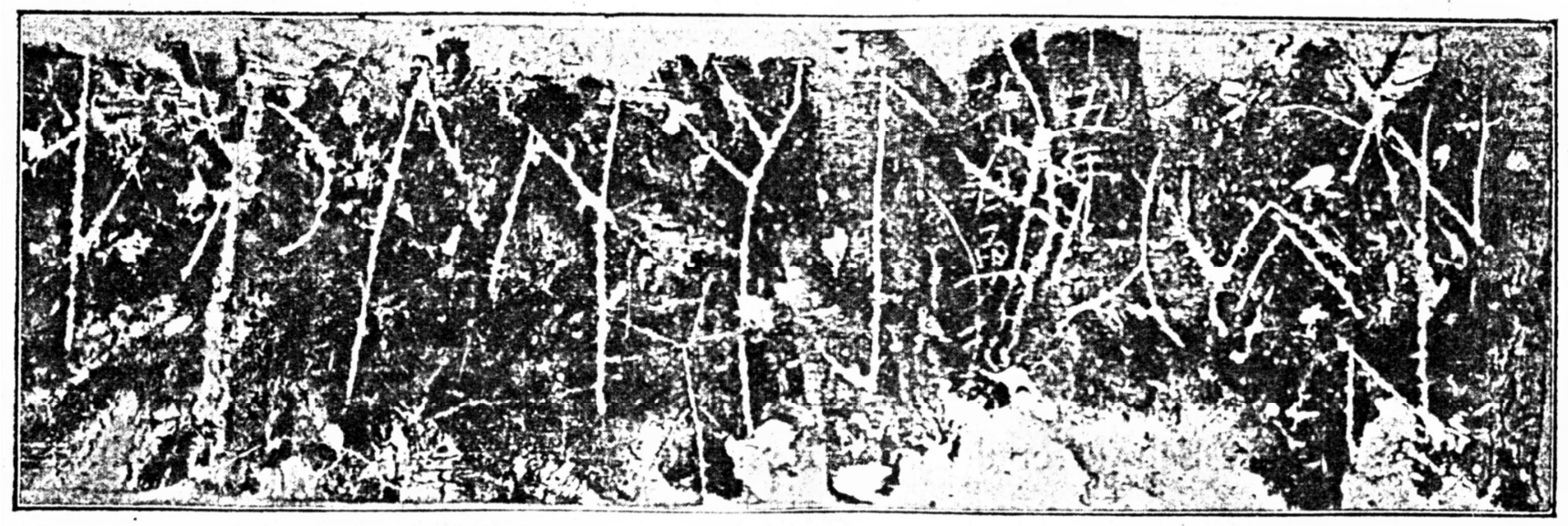

Puc. 5. Яр-хото. Объект VII.

Эстампаж Д. А. Клеменца настенной надписи енисейского письма [Radloff 1899: 82, Abb. 26]

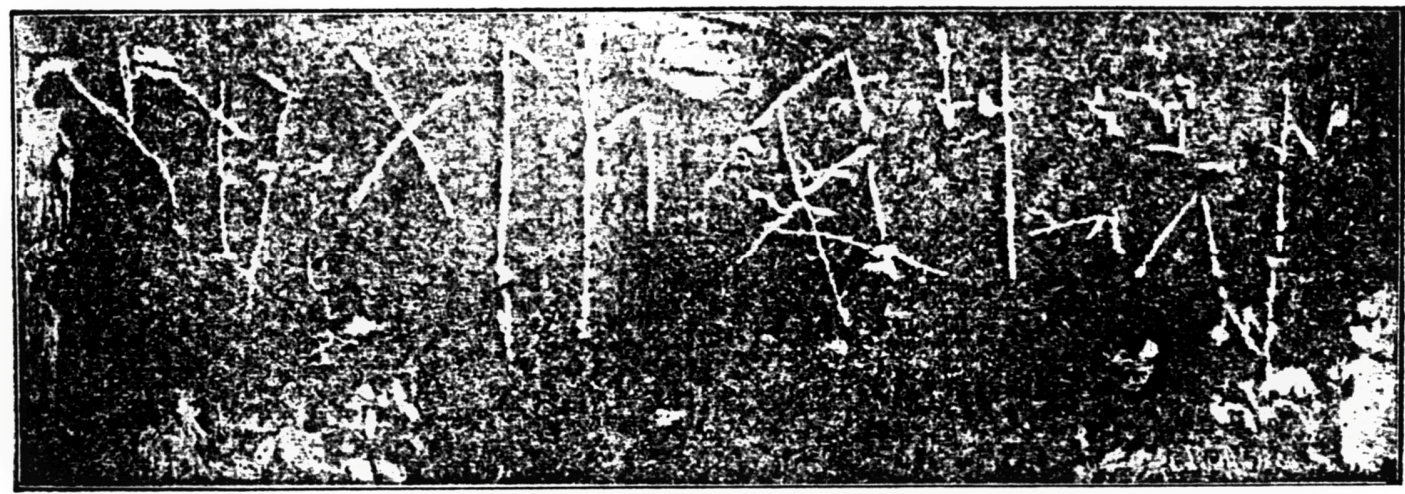

Рис. 6. Яр-хото. Объект VII.

Эстампаж Д. А. Клеменца настенной надписи енисейского письма [Radloff 1899: 82, Abb. 27] 


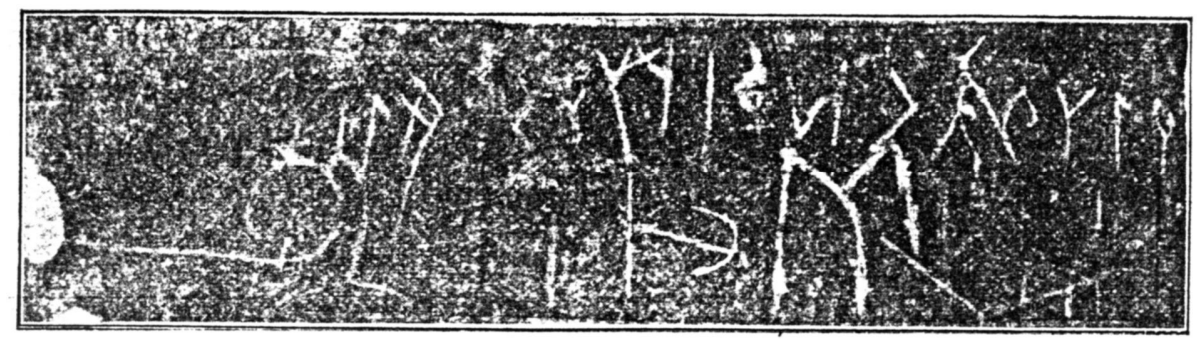

Pис. 7. Яр-хото. Объект VII.

Эстампаж Д. А. Клеменца настенных надписей енисейского письма [Radloff 1899: 82, Abb. 28]

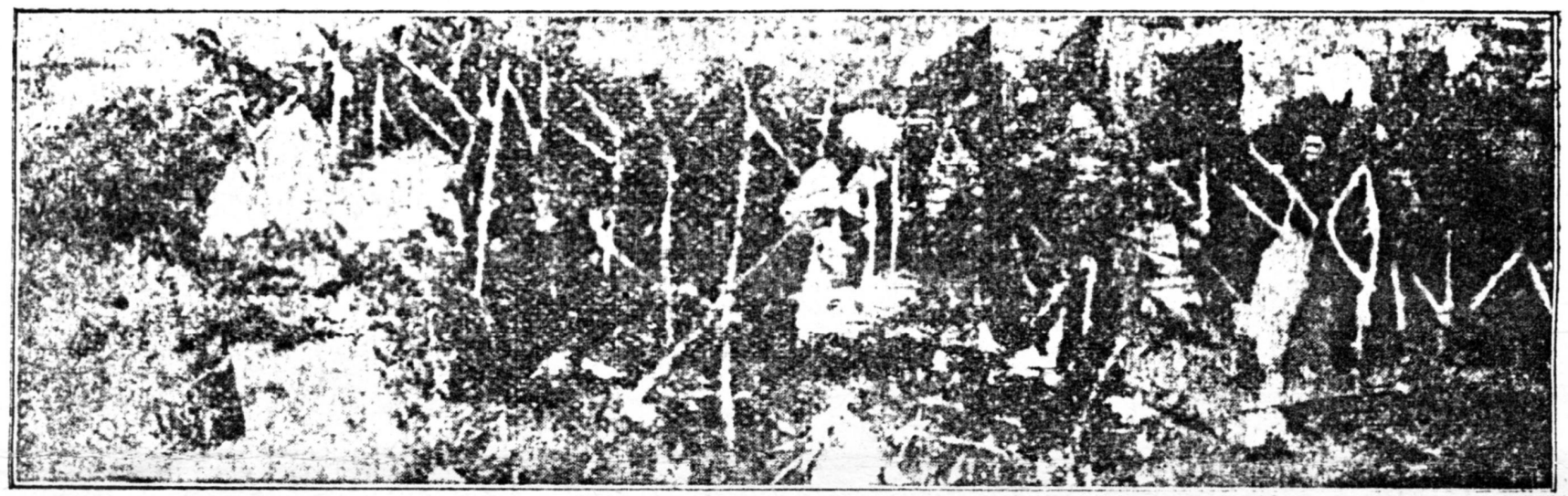

Рис. 8. Яр-хото. Объект VII.

Эстампаж Д. А. Клеменца настенной надписи енисейского письма [Radloff 1899: 82, Abb. 29]

Для понимания кратких рунических надписей мало лишь лингвистического подхода. Важнейшее условие для этого - определение назначения оставленных лаконичных начертаний. В отношении граффити Яр-хото предстоит также установить конфессиональную принадлежность писавших. Без всего этого невозможно понять культурное значение эпиграфики в обществах раннего средневековья.

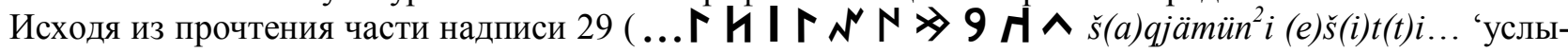
шал Шакьямуни...') (рис. 8), В. В. Радлов полагал, что авторы граффити были буддистами [Radloff 1899: 82]. С. Г. Кляшторный также считал, что «по конфессиональной принадлежности все мелкие надписи (Восточного Туркестана. - И. К.) созданы в буддийской среде» [Кляшторный 1992: 338; 2003: 375; 2010 : 278]. Сергей Григорьевич не учел существования внутри буддийских монастырей манихейских общин. Такое сосуществование не противоречило ни доктрине манихейства, вслед за пророком воспринимавшей Будду предшественником самого Мани, ни факту официального положения этой религии в уйгурских княжествах Восточного Туркестана. Связь енисейской письменности с вероисповеданием Мани, ставшим государственной идеологией Древнехакасского государства, показана на конкретных материалах [Кызласов Л. Р. 1998; Кызласов 1999а, 2001] ${ }^{4}$.

Эпиграфические находки свидетельствуют: в IX-X вв. носители енисейского письма - древние хакасы - приезжали в духовные центры Турфана ${ }^{5}$. Но они не относились к лицам, «которые только временно пребывают в Турфане, прибыв с севера» [Radloff 1899: 82], и их надписи в Яр-хото не были посетительскими, как считал М. Эрдал [Erdal 1993: 90, 105]. Сомнительно также, что их оставили странствующие паломники с Енисея, как после 2003 г. полагал С. Г. Кляшторный (сообщение В. Д. Рухлядева). Пришедшие с Саяно-Алтая тюркоязычные манихеи, вливаясь в монашеские общины, подолгу проживали в монастырях Восточного Туркестана, углубленно постигая религиозные основы вероучения. Нанесенные на стены жилых пещер граффити отражали их религиозные чувства. И пониматься эти надписи должны соответствующим образом.

${ }^{4} \mathrm{C}$ этих пор указание на Уйгурский каганат как на единственный случай, когда гонимое как ересь манихейство стало государственной религией [Литвинский, Смагина 1992: 524], теряет свое значение. Загадка официального принятия манихейства лишь тремя тюркоязычными государствами (третьим стал Кимакский каганат) остается пока неразгаданной.

${ }^{5}$ Вероятно и более позднее пребывание здесь древних хакасов. Так, на городище Яр-хото найден наконечник стрелы, подобный изделиям аскизской археологической культуры [Jiaohe 2001: 14]. Вопреки указанию в публикации, его следует относить к X-XII вв. 
Изучение сотен наскальных молитвенных надписей енисейского письма позволяет иначе прочитать и понять граффити Яр-хото. В 1994 г. издана прорисовка и новое прочтение строки 27 (рис. 6, 9) -

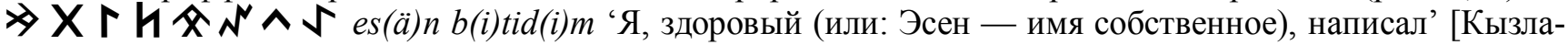
сов 1994: 197, рис. 29]. Ясно начертанная глагольная формула bitidim '(это) я написал' была прочитана и В. В. Радловым [Radloff 1899: Abb. 27], и М. Эрдалом (согласно которому она есть еще в другом граффито Яр-хото (№ 1) [Erdal 1993: 91, 92, 95, 96]), но первое слово этой надписи осталось непонятым. На утесах Саяно-Алтая, почитавшихся носителями енисейского письма, такие лаконичные высказывания, отражающие как совершенное личное моление, так и благодарность за оздоровление верующего, встречены неоднократно [Кызласов 2001: 245-249, 257; 2004: 112-114, 117-120]. М. Эрдал (нумеровавший эстампажи подряд по описи Азиатского музея от № 1 до 10, а далее 21 и 22; так, со знаком №, я и указываю номера строк в труде этого тюрколога) узнал слово еsӓn 'здоровый' еще в двух надписях — №№ 2 и 6 [Erdal 1993: 93 — 95, 98, 99; Radloff 1899: Abb. 28] (рис. 7).

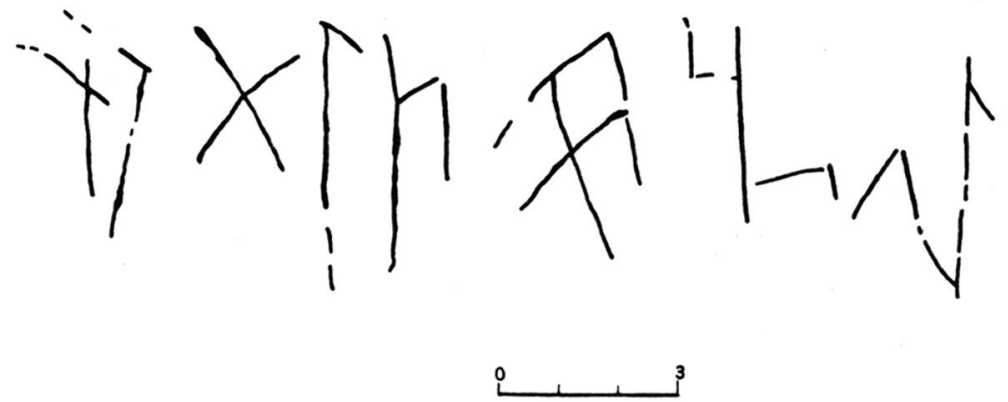

Puc. 9. Яр-хото. Объект VII. Прорисовка надписи по эстампажу Д. А. Клеменца, изданному В. В. Радловым (см. выше рис. 6) [Кызласов 1994: рис. 29]

Слово аtač ‘батюшка' в форме (a)t(a)čc(i)m 'мой батюшка' употреблено, хотя было не сразу опознано тюркологами, в древнехакасской эпитафии Е 32, строка 4 [Clauson 1972: 43; ДТС 1969: 66], а также в Ярхото в строке, изданной В. В. Радловым на илл. 26 (рис. 5). Здесь его узнал М. Эрдал (надпись № 3), прочтение которого можно принять: (a)t(a)čci)ma s(a)qünur '... я думаю о моем батюшке'. Правда, речь здесь может идти не о родственных связях: Отцом в манихейских енисейских надписях называли вер-

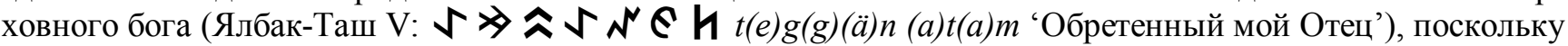
имя Всевышнего было скрыто от верующих (Ялбак-Таш II/XV), которые иногда именовали себя его «сынами человеческими» (Бичикту-Бом II) [Кызласов 2000: 91-97, рис. 4-7; 2001: 247-249, 251, рис. 4, 1; 2003: 26-29, 48 - 57]. Помимо этого, в манихействе «Отцом может называться практически любое светлое божество, порождающее эманации» [Кефалайа 1998: 434 -436]. У глагольной формы saqïn-, встреченной в этом граффито Яр-хото, кроме смысла 'думать, размышлять', есть и значение 'остерегаться, беречься' [ДТС 1969: 486], которое в данном случае, с аффиксом активной залоговой основы -ur-, вполне подходит при религиозном понимании монастырской надписи: ‘Я (духовно) оберегаю моего батюшку'.

Такая трактовка находит поддержку в лексике двух других пещерных надписей (№ 2, дважды, и № 5). Отказавшись от светской посетительской принадлежности настенных граффити, в них не следует видеть отглагольное существительное $j(a) n(i) \check{s}+(i) m$ 'мое возвращение' [Erdal 1993: 93, 94, 96, 97; ДТС 1969: 231]. Скорее, здесь речь трижды идет о страхе - aj(i)n(i)š+(i)m 'моем опасении / моей боязни' [ДТС 1969: 29]. Без контекста надписи невозможно решить, был ли это страх верующего «перед демонами, разрушающими его тело», обличением его греха пастырем или боязнью лишиться вечного пребывания души в благости-эоне [Кефалайа 1998: 41.14; 165.24; 199.16, 19, 26; 236.17—18, 23].

Иначе можно прочесть и снабженное титулом $\boldsymbol{Y}>\boldsymbol{\lambda}$ čor (čur: [ДТС 1969: 157]) личное имя, оставленное автором двух монастырских начертаний и одинаково прочитанных В. В. Радловым [Radloff 1899: 82, Abb. 28] и М. Эрдалом [Erdal 1993: 96, 98, 99, №№ 5b, 6] - $\boldsymbol{\nearrow}$ > $\boldsymbol{\mathcal { C }} \boldsymbol{Y} \boldsymbol{\Gamma} \mathbf{9} \mathrm{Jil}(\mathrm{i}) \mathrm{g}$ čor. М. Эрдал видел в этом имени мягкий (палатальный) вариант первичной твердой формы jïlï 'приветливый' / ilï 'теплый' (см. [ДТС 1969: 218, 266]). Хотя иных фактов его употребления нет, тюрколог привел личные имена сходного значения из памятников уйгурского письма. Возможность такого понимания, пожалуй, подтверждает еще один случай использования в граффити Яр-хото того же титула со столь же лиричным личным именем - Körtlä čor (надпись № 5a), буквальное значение которого 'Красивый/Прекрасный чор'. Вместе с тем руническая орфография позволяет безо всяких фонетических натяжек читать первое мужское имя иначе, как $j(e) l(l)(i) g$ со значением 'вихрь, порывы ветра' (производное от jel 'ветер') [ДТС 1969: 254], хотя употребление такого имени в других письменных памятниках также неизвестно. 
Быть может, имея дело с граффити адептов религии Света, здесь надо принять во внимание тюркские именования светлых сил в манихействе, среди которых находим и jel tä̈ri 'бог-ветер' [там же]. Остается пока неизвестным, увязывались ли такие духовные образы с именословом тюркоязычных манихеев. Подобная связь мужских личных имен с высокими религиозными понятиями, пришедшими в северное манихейство из буддизма, встречена среди енисейских надписей (см. Адыр-Кая I: $\boldsymbol{\boldsymbol { \lambda }} \mathbf{9} \boldsymbol{\boldsymbol { \Lambda }} \boldsymbol{\boldsymbol { \Upsilon }}(e) r(a) t i ̈$ $j e v(i) g$ 'Его имя эра (т. е. свободного полноправного мужчины. - И. К.) - Йевиг’ [Кызласов 2001: 248, рис. 7], где jevig «“снаряжение”, качества бодисатвы, необходимые для просветления» [ДТС 1969: 260]). Титул čor присущ именно памятникам енисейского письма [Малов 1952: 112; Кормушин 2008: 299, 300, 319; Кызласов 1999б: 184; 2019: 262, 263].

Тем самым, по крайней мере три надписи в монастыре Яр-хото оставлены титулованными древнехакасскими аристократами - «происходят от благородных средневековых тюрков», как было отмечено B. В. Радловым [Radloff 1899: 82]. При учете местной политической истории и палеографических примет (особенно вида руны $\widehat{\mathrm{t}^{1}}$ в строке 26) настенные граффити енисейского письма следует отнести к IX-X вв. В то время пребывание родовитых саяно-алтайцев в религиозных общинах Восточного Туркестана и Ганьсу подтверждается находкой рукописного документа в монастырской библиотеке, замурованной в пещере Дуньхуана. Автор-буддист, «рожденный в стране Кыргызской, в самом царствующем Доме», т. е. представитель древнехакасского династийного рода Кыргыз, просил защиты у «общества богов $\langle\ldots\rangle$ ради того, чтобы, завершив в этой жизни все цели обета, он смог сначала достичь своей страны, и в будущих жизнях, где бы ни был рожден, был свободен от страданий и смог не упасть в ад, а мог быть рожденным в царстве богов» [Thomas, Clauson 1927: 281-283; Кызласов Л. Р. 1969: 127; 1984: 141].

Долгое проживание выходцев из благородных семей в пещерном монастыре в Яр-хото, похоже, доказывается как многочисленностью настенных граффити в пещере 3, так и размерами этих надписей. По измерениям М. Эрдала, строки на эстампажах тянутся от 50-65 до 92, 145 (№ 7) и даже 201 см (№ 3-4), в них от 10-14 и 20-29 до 42 и более письменных знаков. В двух надписях одной и той же пещеры трижды встречается имя ее обитателя Йилиг-чора. Все это мало похоже на краткие посещения мимоезжих грамотеев.

C середины IX в. в огромную державу Южной Сибири и Центральной Азии, официально применявшую и распространявшую енисейские руны, были включены регионы, принявшие эту письменную культуру, но отразившие в ней собственные обычаи и письменные традиции. Эти своеобразные локальные черты енисейских памятников воспроизведены и в эпиграфике Восточного Туркестана. Так, упомянутая эпитафия, найденная близ древнего Бешбалыка, по облику необработанного камня, размещению снизу вверх и содержанию лаконичного текста принадлежит к канону, отличавшему Тувинскую котловину [Кызласов 2016]. Столь же своеобразно и самостоятельное употребление в четырех настенных надписях Яр-хото (граффити №№ 2, 3 [Radloff 1899: Abb 26], 5a, 8) после некоторых слов, завершающихся согласным (ajïnï̌im, atačim), руны $\checkmark$ a, обозначавшей вокатив 'о!' (ср.: [ДТС 1969: 1]) (рис. 5). Вводимые в надмогильный текст это и подобные горестные восклицания - характернейшая особенность классических древнехакасских эпитафий, отвечавших канону ритуального плача, с рубежа нашей эры существовавшего в Хакасско-Минусинской котловине на Среднем Енисее [Кызласов 2013: 84-87]. Вместе с алфавитной принадлежностью эта эмоциональная черта молитвенных восклицаний, присущая изучаемым обрядовым начертаниям монастыря в Яр-хото, доказывает приход в Турфанский оазис выходцев из южных долин великой сибирской реки.

Настенные граффити Яр-хото подтверждают манихейскую принадлежность нанесших их авторов еще одним эпиграфическим аргументом. На изданном В. В. Радловым эстампаже [Radloff 1899: Abb 28] ниже основной горизонтальной строки видна еще одна, четырнадцатая зафиксированная экспедицией Д. А. Клеменца енисейская надпись, не учтенная никем из лингвистов. Это единственная крупно начертанная ниже строки руна $\boldsymbol{\Upsilon} r^{2}$ (рис. 7). Нанесенная вне контекста, она читается единственным возможным образом - (e)r 'эр (свободный полноправный мужчина)'. Не раз употребленная обособленно среди молитвенных наскальных надписей, эта руна несет иное, религиозное содержание обозначенного ею слова, отмечая мужчину-эра как обычного представителя бренного и греховного человечества. Духовная обыденность верующего, как во многих иных известных случаях молитвенных анонимных надписей енисейского письма, не предполагала обозначения его имени - бог знает того, кто к нему обращается. Мне известно 14 несомненных граффити и один вероятный случай такого использования руны $\uparrow r^{2}$. Все они входят в ареал енисейского рунического письма и служат отметкой молитвы, совершенной в том месте верующим манихеем [Кызласов 2019]. Ныне свод этих предельно кратких молитвенных отметок должен быть дополнен указанным пещерным граффити, вводящим Турфанский оазис в круг надписей, отразивших религиозное самовосприятие северных, сибирско-тюркских манихеев. 
Большинство храмовых и жилых пещер в монастырях Восточного Туркестана однокамерные, реже двухкамерные - прямоугольные или квадратные [Литвинский, Пичикян 1986: 91-113, рис. 1-13, 15, 16; Литвинский 2000: 27—48, табл. 4-7, 12]. В редких случаях они имеют боковые малые пещеры, расположенные друг против друга - в Мин-уе у Кумтуры их две, отходящих от вестибюля, в Шикшине шесть [Литвинский 2000: 44, 57 рис. 7, 4; Дьяконова 1995: 43, табл. 58, 59]. Но экспедицией Д. А. Клеменца в монастырях близ Туюк-мазара и Яр-Хото были зафиксированы еще более сложные типы пещер, по планировке лишь формально сопоставимые с последними [Литвинский 2000: 56—57]. Именно на них нам следует обратить особое внимание.

По свидетельству Д. А. Клеменца, енисейские надписи в монастыре Яр-хото найдены в пещерах 3 и 6 , что подтверждено описанием С. М. Дудина. Согласно плану этого Объекта VII, обе жилые пещеры не только входили в единый комплекс из 8 сооружений, но и соседствовали с центральной пещерой 4 главным здешним храмом. Сама его форма - основной зал с пятью отдельными камерами (рис. 3 и 10) указывает на манихейскую сущность монастыря. Именно эта особенность культовой архитектуры, не свойственная сооружениям иных вероисповеданий, предоставляет еще одно доказательство манихейской принадлежности наших надписей.

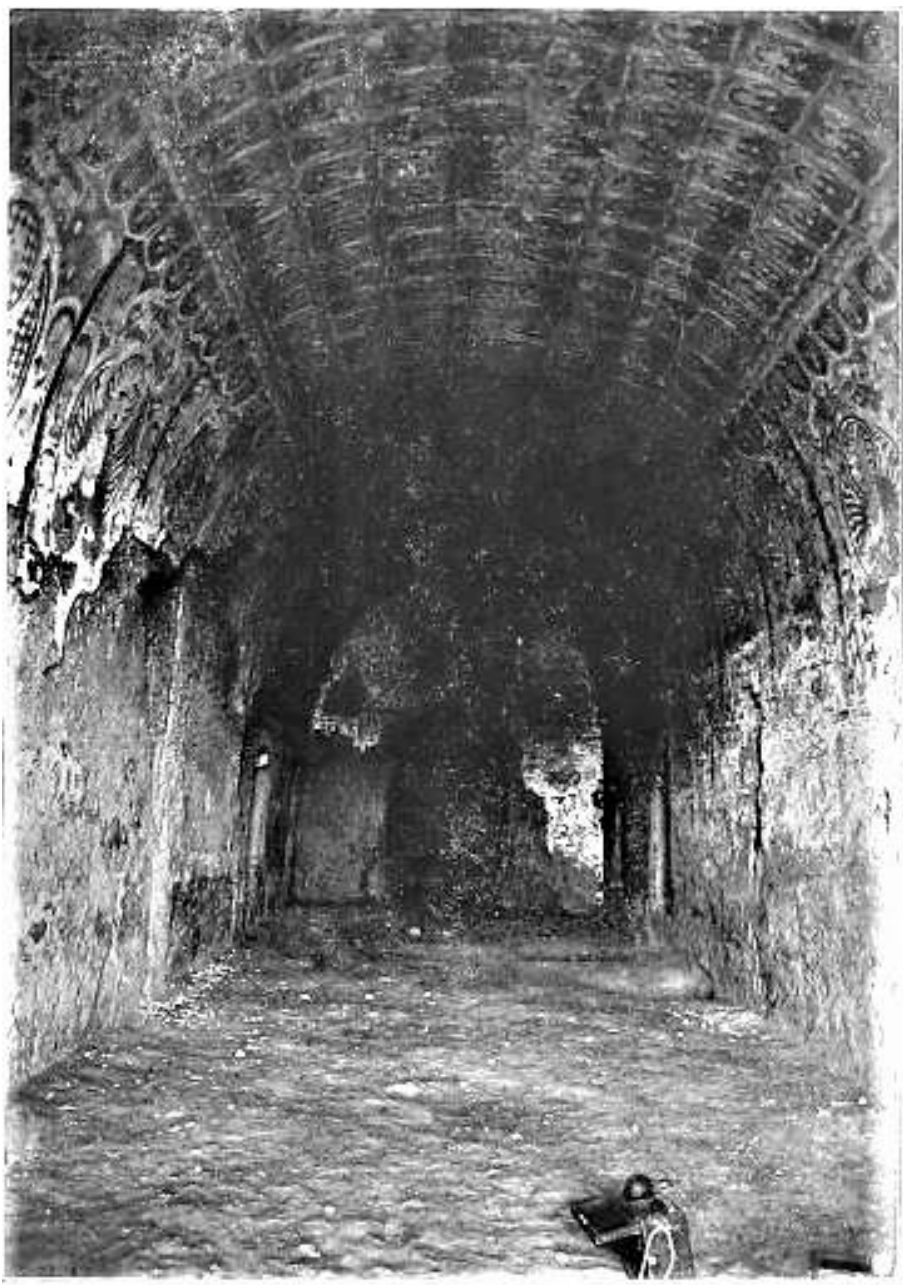

Puc. 10. Яр-хото. Объект VII, пещера 4. Центральный храм манихейского монастыря.

Видны проходы в 5 дополнительных камер [Klementz 1899: Pl. 3]

Найденное в Дуньхуане сжатое изложение на китайском языке «доктрин и направлений учений Мани, Будды Света» указывает назначение характерных для манихейской религии Восточного Туркестана и Китая пяти смежных храмовых помещений:

- одно для священных книг и картин (изображений);

- одно для поста и объяснений (толкований);

- одно для поклонения (молитвы) и покаяния;

- одно для преподавания (обучения);

— одно для больных монахов (верующих) [Бартольд 1927: 45; 1963: 218; Беленицкий 1954: 65]. 
Здесь соответственно даны два близких по терминологии перевода французской и английской передачи китайских религиозных терминов, определяющих назначение манихейских культовых помещений. См. также [Литвинский, Смагина 1992: 530].

Экспедицией Д. А. Клеменца была, как сказано, обнаружена, описана и зафиксирована чертежом еще одна пещера такой же характерной формы [Klementz 1899: 37, Abb. 11] (рис. 11). Она принадлежала к одному из пещерных монастырей урочища Тойок (близ д. Тойок-Мазар), откуда происходят две учебные записи позднеорхонского алфавита [Кызласов 1994: 106-109, рис. 10, 11]. Они неопровержимо свидетельствуют, что уже грамотные монахи, готовясь к миссионерской деятельности, учили руны одну из систем письма, помимо собственной, официально принятую именно и только манихейской церковью [Габен фон 1986: 170, 171].

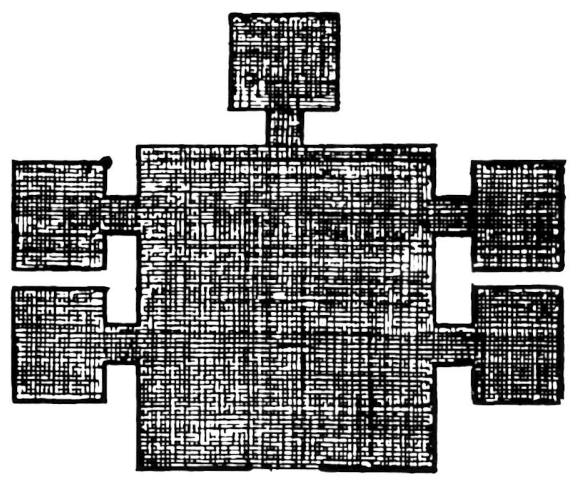

Puc. 11. Урочище Тойок. План храмовой пещеры с 5 дополнительными камерами [Klementz 1899: Abb. 11]

Итак, рассмотрение памятников эпиграфики, открытых Д. А. Клеменцем в 1898 г., позволяет не только включить в ареал енисейской рунической письменности Турфанский оазис и один из его пещерных монастырских комплексов, но и определяет молитвенное назначение его настенных граффити. Помимо этого, манихейская принадлежность Объекта VII близ Яр-хото, устанавливаемая по его характерному архитектурному облику, подтверждает связь официальной системы письма Древнехакасского государства с манихейским вероисповеданием.

Перед нами новое доказательство существования северного, сибирско-тюркского манихейства.

Реальность существования этой ветви вероучения Света была выявлена недавно. К открытию привели раскопки и осмысление сакральных архитектурных особенностей монументальных раннесредневековых храмов на Среднем Енисее, сохранивших месопотамскую сабейскую традицию [Кызласов Л. Р. 1998, 1999, 2001], анализ содержания [Кызласов 2001] и выделение своеобразного типа орфографии памятников енисейской письменности [Кызласов 1996, 1997, 1999а].

\section{Литература}

Акрамова, Акрамов 1973 - Акрамова X. Ф., Акрамов Н. М. Востоковед Михаил Степанович Андреев (Научнобиографический очерк). Душанбе, 1973 // https://eu-spb.academia.edu/SergeyAbashin. \{Akramova H. F., Akramov N. M. Orientalist Mikhail Stepanovich Andreev (Scientific and biographical sketch). Dushanbe, 1973 // https://eu-spb.academia. edu/SergeyAbashin.\}

Бартольд 1927 - Бартольд В. В. История культурной жизни Туркестана. Л., 1927. \{Bartold V. V. The history of the cultural life of Turkestan. Leningrad, 1927.\}

Бартольд 1963 - Бартольд В. В. История культурной жизни Туркестана // Сочинения. Т. II. Часть 1. М., 1963. C. 165-433. \{Bartold V. V. The history of the cultural life of Turkestan // Works. Vol. II. Part 1. Moscow, 1963. P. $165-433$.

Беленицкий 1954 - Белениџкий $A$. М. Вопросы идеологии и культуры Согда по материалам пянджикентских храмов // Живопись древнего Пянджикента. М., 1954. С. 8-82. \{Belenickij A. M. Issues of ideology and culture of Sogd based on materials from the Panjikent temples // Painting of ancient Pyandjikent. Moscow, 1954. P. 8-82.\}

Бичурин 1950 - Бичурин Н. Я. Собрание сведений о народах, обитавших в Средней Азии в древние времена. Т. II. М.-Л., 1950. \{Bichurin N. Ya. Collection of information about the peoples who lived in Central Asia in ancient times. T. II. Moscow — Leningrad, 1950.\}

Бухарин, Инкина 2018 - Бухарин М. Д., Инкина Н. В. Путевой дневник Д. А. Клеменца // Восточный Туркестан и Монголия. История изучения в конце XIX — первой трети XX века. Т. II. М., 2018. С. 207—274 // 
http://ranar.spb.ru/files/visual/pdf/Turkestan_T.\%20II compressed.pdf. \{Buharin M. D., Inkina N. V. D. A. Klemenz's travel diary // East Turkestan and Mongolia. The history of the study at the end of the XIX - the first third of the XX century. Vol. II. Moscow, 2018. P. 207-274 // http://ranar.spb.ru/files/visual/pdf/Turkestan T.\%20II compressed.pdf.

Бухарин, Шевельчинская 2018 - Бухарин М. Д., Шевельчинская С. Л. Фотоархив Турфанской экспедиции Д. А. Клеменца 1898 г. // Восточный Туркестан и Монголия. История изучения в конце XIX - первой трети XX века. T. II. M., 2018. C. 275-384 // http://ranar.spb.ru/files/visual/pdf/Turkestan_T.\%20II_compressed.pdf. \{Buharin M. D., Shevelchinskaya S. L. Photo archive of the D. A. Klemenz's Turfan expedition in 1898 // East Turkestan and Mongolia. The history of the study at the end of the XIX — the first third of the XX century. Vol. II. Moscow, 2018. P. 275-384 // http://ranar.spb.ru/files/visual/pdf/Turkestan T.\%20II compressed.pdf.\}

Васильев 1983а - Васильев Д. Д. Графический фонд памятников тюркской рунической письменности азиатского ареала (Опыт систематизации). М., 1983. \{Vasilyev D. D. Graphic fund of monuments of the Turkic runic writing of the Asian area (Experience of systematization). Moscow, 1983.\}

Васильев 19836 - Васильев Д. Д. Корпус тюркских рунических памятников бассейна Енисея. Л., 1983. \{Vasilyev D. D. Corpus of Turkic runic monuments of the Yenisei basin. Leningrad, 1983.\}

Габен фон 1986 - Габен А. фон. Культура письма и печатания у древних тюрков // Зарубежная тюркология. Вып. 1. Древние тюркские языки и литературы. М., 1986. С. 159-190. \{Gaben A. fon. The culture of writing and printing among the ancient Türks // Foreign Türkology. Iss. 1. Ancient Turkic languages and literatures. Moscow, 1986. P. 159-190.\}

ДТС 1969 - Древнетюркский словарь. Л., 1969. \{Ancient Türkic dictionary. Leningrad, 1969.\}

Дудин 1916а - Дудин С. М. Архитектурные памятники Китайского Туркестана // Архитектурно-художественный еженедельник, 1916, май, июнь, № 19, 22. С. 217-220, 241-246// https://electro.nekrasovka.ru/books/1419. \{Dudin S. M. Architectural monuments of Chinese Turkestan // Architectural and Art Weekly, 1916, May, June, № 19, 22. P. 241-246 // https://electro.nekrasovka.ru/books/1419.\}

Дудин 1916 - Дудин С. М. Архитектурные памятники Китайского Туркестана. (Из путевых записок). Отдельные оттиски из № 6, 10, 12, 19, 22, 28 и 31 журнала «Архитектурно-художественный еженедельник» за 1916 г. Петроград, 1916. \{Dudin S. M. Architectural monuments of Chinese Turkestan. (From travel notes). Selected reprints from No. 6, 10, 12, 19, 22, 28 and 31 of the magazine "Architectural and Art Weekly" for 1916. Petrograd, 1916.\}

Дьяконова 1995 - Дьяконова Н. В. Шикшин. Материалы Первой Русской Туркестанской экспедиции академика С. Ф. Ольденбурга. 1909-1910. М., 1995. \{Dyakonova N. V. Shikshin. Materials of the First Russian Turkestan Expedition of Academician S. F. Oldenburg. 1909-1910. Moscow, 1995.\}

Кефалайа 1998 - Кефалайа («Главы»). Коптский манихейский трактат. Пер., иссл., комм., глосс. и указ. Е. Б. Смагиной. М., 1998. \{Kefalaya (“Chapters”). Coptic Manichean Treatise. Translation, research, comments, gloss and ind. by E. B. Smagina. Moscow, 1998.\}

Клеменц. Краткий перечень - Клеменц Д. А. Краткий перечень главнейших сведений о состоянии культуры в Восточном Туркестане (рукопись) // Архив ИВР РАН. Ф. 28, оп. 1, д. 126 [Кляшторный 1992: 594; 2003: 512]. $\{$ Klemenz D. A. A short list of the main information about the state of culture in East Turkestan (manuscript) // Archive of the Institute of Oriental Manuscripts of the Russian Academy of Sciences. F. 28, op. 1, d. 126.\}

Клеменц. Описание - Клеменц Д. А. Описание древних городов и пещер в Турфанской земле в Турфанской земле, сделанные (так! - И. К.) во время путешествия 1898 г. // Архив ИВР РАН. Ф. 28, оп. 1, д. 137 [Кляшторный 1992: 594\}. \{Klemenz D. A. Description of ancient cities and caves in the Turfan land in the Turfan land, made during a trip in 1898 // Archive of the Institute of Oriental Manuscripts of the Russian Academy of Sciences. F. 28, op. 1, d. 137.\}

Кляшторный 1964 - Кляшторный C. Г. Древнетюркские рунические памятники как источник по истории Средней Азии. М., 1964. \{Klyashtornyj S. G. Ancient Turkic runic monuments as a source on the history of Central Asia. Moscow, 1964.\}

Кляшторный 1992 - Кляшторный С. Г. Памятники древнетюркской письменности // Восточный Туркестан в древности и раннем средневековье. Этнос, языки, религии. М., 1992. С. 326-369. \{Klyashtornyj S. G. Monuments of ancient Turkic writing // East Turkestan in antiquity and early Middle Ages. Ethnicity, languages, religions. Moscow, 1992. Р. 326-369.\}

Кляшторный 2003 - Кляшторный С. Г. История Центральной Азии и памятники рунического письма. СПб., 2003. C. 358 - 413. \{Klyashtornyj S. G. History of Central Asia and monuments of runic writing. St. Petersburg, 2003. Р. $358-413$.

Кляшторный 2010 - Кляшторный С. Г. Рунические памятники Уйгурского каганата и история евразийских степей. СПб., 2010. \{Klyashtornyj S. G. Runic monuments of the Uyghur Kaganate and the history of the Eurasian steppes. St. Petersburg, 2010.\}

Кляшторный, Лубо-Лесниченко 1974 - Кляшторный С. Г., Лубо-Лесниченко Е. И. Бронзовое зеркало из Восточного Туркестана с рунической надписью // Сообщения Государственного Эрмитажа. Вып. ХХХІХ. Л., 1974. C. 45-48. \{Klyashtornyj S. G., Lubo-Lesnichenko E. I. Bronze mirror from East Turkestan with a runic inscription // Messages from the State Hermitage. Iss. XXXIX. Leningrad, 1974. P. 45-48.\} 
Кормушин 2008 - Кормушин И. В. Тюркские енисейские эпитафии. Грамматика, текстология. М., 2008. \{Kormushin I. V. Turkic Yenisei epitaphs. Grammar, textual criticism. Moscow, 2008.\}

Крюков 1988 - Крюков М. В. Восточный Туркестан в III в. до н. э. - VI н. э. // Восточный Туркестан в древности и раннем средневековье. Очерки истории. М., 1988. С. 223-296. \{Kryukov M. V. Eastern Turkestan in the III century. BC. — VI AD // East Turkestan in antiquity and early Middle Ages. History essays. Moscow, 1988. P. 223 - 296.\}

Кызласов 1994 - Кызласов И. Л. Рунические письменности евразийских степей. М., 1994. \{Kyzlasov I. L. Runic scripts of the Eurasian steppes. Moscow, 1994.\}

Кызласов 1996 - Кызласов И. Л. Три типа древнетюркской рунической орфографии // 90 лет Н. А. Баскакову. M., 1996. C. 124-136. \{Kyzlasov I. L. Three types of ancient Turkic runic spelling // 90 years of N. A. Baskakov. Moscow, 1996. P. 124-136.\}

Кызласов 1997 - Кьзласов И. Л. Разновидности древнетюркской рунической орфографии. Отражение манихейской письменной культуры в памятниках енисейского и орхонского письма // Acta Orientalia Academiae Scientiarum Hungaricae. Budapest, 1997. T. L, fasc. 1-3. C. 163-184. \{Kyzlasov I. L. Varieties of the ancient Turkic runic spelling. Reflection of the Manichean written culture in the monuments of the Yenisei and Orkhon writing // Acta Orientalia Academiae Scientiarum Hungaricae. Budapest, 1997. T. L, fasc. 1-3. P. 163-184.\}

Кызласов 1999а - Кызласов И. Л. Орфографические признаки манихейских рунических надписей // Вопросы тюркской филологии. Вып. IV. М., 1999. С. 85-112. \{Kyzlasov I. L. Spelling signs of Manichean runic inscriptions // Questions of Turkic philology. Iss. IV. Moscow, 1999. P. 85-112.\}

Кызласов 19996 - Кьзласов И. Л. Наскальная история Западной Монголии // Природные условия, история и культура Западной Монголии и сопредельных регионов. Тезисы докладов. Томск, 1999. С. 182-183. \{Kyzlasov I. L. Rock history of Western Mongolia // Natural conditions, history and culture of Western Mongolia and adjacent regions. Abstracts. Tomsk, 1999. P. 182-183.\}

Кызласов 2000 - Кызласов И. Л. Памятники рунической письменности в собрании Горно-Алтайского республиканского краеведческого музея // Древности Алтая. № 5. Горно-Алтайск, 2000. С. 82-112. \{Kyzlasov I. L. Monuments of runic writing in the collection of the Gorno-Altai Republican Museum of Local Lore // Antiquities of Altai. № 5. Gorno-Altaysk, 2000. P. 82-112.\}

Кызласов 2001 - Кызласов И. Л. Смена мировоззрения в Южной Сибири в раннем средневековье (Идеи единобожия в енисейских надписях) // Древние цивилизации Евразии. История и культура. М., 2001. С. 243-270. $\{$ Kyzlasov I. L. Change of worldview in Southern Siberia in the early Middle Ages (Ideas of monotheism in the Yenisei inscriptions) // Ancient civilizations of Eurasia. History and culture. Moscow, 2001. P. 243-270.\}

Кызласов 2003 - Кызласов И. Л. Новости тюркской рунологии. Вып. 1. Енисейские надписи на горе ЯлбакТаш (Горный Алтай). М., 2003. \{Kyzlasov I. L. News of the Turkic runology. Iss. 1. Yenisei inscriptions on the YalbakTash mountain (Gorny Altai). Moscow, 2003.\}

Кызласов 2004 - Кызласов И. Л. Удаль витязя и благочестие попа (Шаханшах Варахран I, пророк Мани и рунические надписи горы Дэл-ула в Монголии) // Памятники археологии и древнего искусства Евразии. М., 2004. C. 104-122. \{Kyzlasov I. L. The courage of the knight and the piety of the priest (Shahanshah Varakhran I, the prophet Mani and the runic inscriptions of Mount Del-ula in Mongolia) // Monuments of archeology and ancient art of Eurasia. Moscow, 2004. P. 104-122.\}

Кызласов 2013 - Кызласов И. Л. Религиозная природа енисейской письменности. I // Российская тюркология. 2013, 2. C. 79-90. \{Kyzlasov I. L. The religious nature of the Yenisei writing. I // Russian Turkology. 2013, 2. P. 79-90.\}.

Кызласов 2016 - Кызласов И. Л. Енисейская эпитафия из Восточного Туркестана // Тюрко-монгольский мир в прошлом и настоящем. СПб. - Улан-Батор, 2016. С. 218-230. \{Kyzlasov I. L. Yenisei epitaph from East Turkestan // Turkic-Mongolian world in the past and present. St. Petersburg — Ulan-Bator, 2016. P. 218 - 230.\}

Кызласов 2019 - Кызласов И. Л. Свидетельства дальнего продвижения енисейского рунического письма на запад (Одна из форм самовосприятия в северном манихействе) // Звучат лишь письмена. К юбилею А. А. Медынцевой. M., 2019. C. 251-290. \{Kyzlasov I. L. Evidence of the distant advancement of the Yenisei runic writing to the west (One of the forms of self-perception in northern Manichaeism) // Only letters sound. On the anniversary of A. A. Medyntseva. Moscow, 2019. P. 251-290.\}

Кызласов Л. Р. 1969 - Кызласов Л. Р. История Тувы в средние века. М., 1969. \{Kyzlasov L. R. History of Tuva in the Middle Ages. Moscow, 1969.\}

Кызласов Л. Р. 1984 - Кызласов Л. Р. История Южной Сибири в средние века / Библиотека историка. М., 1984. \{Kyzlasov L. R. History of Southern Siberia in the Middle Ages / Historian's Library. Moscow, 1984.\}

Кызласов Л. Р. 1998 - Кызласов Л. Р. Северное манихейство и его роль в культурном развитии народов Сибири и Центральной Азии // Вестник Московского университета. Серия 8. История. 1998, 3. C. 8-35. \{Kyzlasov L. R. Northern Manichaeism and its role in the cultural development of the peoples of Siberia and Central Asia // Bulletin of Moscow University. Series 8. History. 1998, 3. P. 8-35.\} 
Кызласов Л. Р. 1999 - Кызласов Л. Р. Манихейский храм в котловине Сорга (Республика Хакасия) // Российская археология. 1999, 2. С. 181-206. \{Kyzlasov L. R. Manichean temple in the Sorga basin (Republic of Khakassia) // Russian archeology. 1999, 2. P. 181-206.\}

Кызласов Л. Р. 2001 - Кызласов Л. Р. Сибирское манихейство // Этнографическое обозрение. 2001, 5. С. 83 -90. \{Kyzlasov L. R. Siberian Manichaeism // Ethnographic Review. 2001, 5. P. 83-90.\}

Литвинский 2000 - Литвинский Б. А. Архитектура и строительное дело // Восточный Туркестан в древности и раннем средневековье. Архитектура. Искусство. Костюм. М., 2000. С. 13-217. \{Litvinskij B. A. Architecture and construction // East Turkestan in antiquity and early Middle Ages. Architecture. Art. Costume. Moscow, 2000. P. 13-217.\}

Литвинский, Пичикян 1986 - Литвинский Б. А., Пичикян И. Р. Пещерная культовая архитектура Восточного Туркестана // Восточный Туркестан и Средняя Азия в системе культур древнего и средневекового Востока. М., 1986. C. 81-125. \{Litvinskij B. A., Pichikyan I. R. Cave cult architecture of East Turkestan // East Turkestan and Central Asia in the system of cultures of the ancient and medieval East. Moscow, 1986. P. 81-125.\}

Литвинский, Смагина 1992 - Литвинский Б. А., Смагина Е. Б. Манихейство // Восточный Туркестан в древности и раннем средневековье. Этнос, языки, религии. М., 1992. С. 508-532. \{Litvinskij B. A., Smagina E. B. Manichaeism // Eastern Turkestan in antiquity and early Middle Ages. Ethnicity, languages, religions. Moscow, 1992. P. 508-532.\}

Литвинский, Терентьев-Катанский 1988 - Литвинский Б. А., Терентьев-Катанский А. П. История изучения // Восточный Туркестан в древности и раннем средневековье. Очерки истории. М., 1988. С. 17-82. \{Litvinskij B. A., Terentyev-Katanskij A. P. History of the study // East Turkestan in antiquity and the early Middle Ages. History essays. Moscow, 1988. P. 17-82.\}

Малов 1952 - Малов С. E. Енисейская письменность тюрков. М.-Л., 1952. \{Malov S. E. Yenisei writing of the Turks. Moscow — Leningrad, 1952.\}

Малявкин 1974 - Малявкин А. Г. Материалы по истории уйгуров в IX-XII вв. / История и культура Востока Азии. Т. II. Новосибирск, 1974. \{Malyavkin A. G. Materials on the history of the Uighurs in the $9^{\text {th }}-12^{\text {th }}$ centuries. $/$ History and culture of East Asia. Vol. II. Novosibirsk, 1974.

MPC 1957 - Монгольско-русский словарь. М., 1957. \{Mongolian-Russian dictionary. Moscow, 1957.$\}$

Ольденбург 1917 - Ольденбург С. Ф. Экспедиция Д. А. Клеменца в Турфан в 1898 г. // Известия ВосточноСибирского Отдела Русского Географического Общества. Иркутск, 1917. Т. 45. Отд. оттиск. 13 c. // http://www. orientalstudies.ru/rus/index.php?option=com_publications\&Itemid=75\&pub=7397. \{Oldenburg $S . \quad F$. Expedition of D. A. Klemenz to Turfan in 1898 // Bulletin of the East Siberian Department of the Russian Geographical Society. Irkutsk, 1917. Vol. 45. Dept. imprint. 13 p. // http://www.orientalstudies.ru/rus/index.php?option=com_publications\&Itemid=75\& $\mathrm{pub}=7397$.

Попов 1925 - Попов И. И. Д. А. Клеменц. Его жизнь и деятельность // Д. А. Клеменц. Из прошлого. Воспоминания. Л., 1925. С. 7—66 // https://rusneb.ru/catalog/000199 000009002598309 . \{Popov I. I. D. A. Klemenz. His life and work // D. A. Klemenz. From past. Memories. Leningrad, 1925. P. 7-66 // https://rusneb.ru/catalog/ 000199000009002598309$.

Туманова 1989 - Туманова О. А. Городище Яр-хото // Труды Государственного Эрмитажа. Т. XXVII. Л., 1989. C. 15-56. \{Tumanova O. A. The settlement of Yar-khoto // Proceedings of the State Hermitage. Vol. XXVII. Leningrad, 1989. P. $15-56$.

Clauson 1972 - Clauson G. sir. An Etymological Dictionary of Pre-Thirteenth-Century Turkish. Oxford, 1972.

Erdal 1993 - Erdal M. The runic graffiti at Yar Khoto // Türk Dilleri Araştırmaları. 1993, 3. P. 87-108 // https://unifrankfurt.academia.edu/MarcelErdal; https://uni-frankfurt.academia.edu/MarcelErdal (всюду нет с. 102).

Jiaohe 2001 - The Ancient City of Jiaohe. Experience the Beauties of City-State and Ancient Capital on the Silk Road. Urumchi, 2001. (на кит. и англ. яз.)

Klements 1899 - Klements D. Turfan und Seine Altertümer // Nachrichten über die von der Kaiserlichen Akademie der Wissenschaften zu St. Petersburg im Jahre 1898 ausgerüstete Expedition nach Turfan. SPb., 1899. H. 1. P. 1-53 + 8 Pl.

Radloff 1899 - Radloff W. Altuigurische Sprachproben aus Turfan // Nachrichten über die von der Kaiserlichen Akademie der Wissenschaften zu St. Petersburg im Jahre 1898 ausgerüstete Expedition nach Turfan. SPb., 1899. H. 1. P. 55-83.

Thomas, Clauson 1927 - Thomas F. W., Clauson G. L. M. A Second Chinese Buddhist Text in Tibetan Characters // The Journal of the Royal Asiatic Society of Great Britain and Ireland. April 1927. London, 1927. P. 281—306. 